\title{
Croatian Public Relations Terminology - Overview and Guidelines for Terminological Regulation ${ }^{1}$
}

Preliminary communication _ DOI 10.22522/cmr20170222 _ received on 18 July 2017 UDK 001.4:659.4

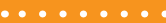

\section{Lana Hudeček}

Institute of Croatian Language and Linguistics, Croatia. Email: Ihudecek@ihjj.hr

\section{Igor Ćutuk}

Croatian Radiotelevision, Croatia. Email: igor.cutuk@hrt.hr (corresponding author)

\section{Abstract}

In this paper, the authors give an overview of Croatian terminology in public relations and point out its functional stratification and the need for its regulation, for which they present specific guidelines. Using examples of synonymous pairs and sequences in public relations terminology currently used in Croatian they demonstrate in detail the application of basic and supplemental principles of terminology standardization and explain the criteria based on which a certain term is given precedence over another or others in the terminology standardization process. In the final chapter guidelines are provided for the compilation of a relevant, corpus-based and normative public relations dictionary conceptualized in line with topical e-lexicography criteria in relation to specialized (terminology) dictionaries. The appendix to this paper contains a brief normative monolingual Croatian public relations dictionary.

Keywords: Croatian language, public relations terminology, terminology standardization, professional jargon, terminological dictionary, e-terminography

1 This paper was drawn up within the framework of the project Hrvatski mrežni rječnik-Mrežnik (IP-2016-06-2141), which is financed by the Croatian Science Foundation. The project leader is Lana Hudeček; the project is being implemented at the Institute for Croatian Language and Linguistics until 28 February 2021. 


\section{Introduction}

As of 1 July 2013, Croatian became the $24^{\text {th }}$ official language of the European Union. This fact encompasses the obligation that various regulatory texts are translated into Croatian, which implies that the Croatian language has professional terms in place for all fields. As a result, particular attention is paid in Croatia to regulating professional terminology, particularly the terminology of those professions whose terminology has not been regulated so far because of their relative newness in Croatia. The regulation of professional terminology is backed and supported financially by the Croatian Science Foundation within the framework of the Struna (Hrvatsko strukovno nazivlje) project that is being implemented at the Institute of Croatian Language and Linguistics, the institution coordinating the project. Within the framework of this project, the terminology of 27 professions has been or is being regulated. ${ }^{2}$

That the specific circumstances of Croatian professional terminology have been clearly recognized in the Croatian academic community is also evidenced by the fact that in the first round of a tender for the financing of research and installation research projects in 2013 the Croatian Science Foundation accepted applications exclusively in English. Subsequently, following requests by the academic community, applications have to be submitted both in Croatian and English, which is extremely important in light of the need for paying greater attention to the establishment of Croatian professional terminology. The new Rulebook on Awarding of Academic Titles (Pravilnik o izboru u znanstvena zvanja) published in March 2017 prescribes that applicants for academic titles must have published at least one paper in Croatian to be awarded the title research associate and for each higher title one paper in Croatian published after the last title awarding. ${ }^{3}$ The great need for the regulation of professional terminology at this point is also evidenced by the frequent inquiries by Croatian translation services in Brussels and Luxemburg submitted almost daily to linguistic experts at the Institute of Croatian Language and Linguistics and

2 The terminology of the following fields has been or is being regulated: anatomy and physiology, antique archeology, anthropology, stone age archeology, marine engineering, wood technology, pharmacology, phytomedicine, physics, genetics, construction, hydraulics and pneumatics, cartography and geoinformatics, chemistry, chemical and laboratory terminology, corrosion and material protection, mathematics, musicology, ophthalmology, paleontology, polymers, maritime studies, EU law, dentistry, machine elements, military terminology, aeronautics.

3 "(14) To be awarded the academic title research associate, applicants must have published at least one scientific paper in standard Croatian, to be awarded each higher title, applicants must have published at least one scientific paper in standard Croatian afer the last title awarding." (Rulebook on Awarding of Academic Titles) 
professional communities. A noticeable number of inquiries pertains to public relations. The need for terminology regulation has been pointed out in papers by experts of various professions, e.g. in the field biomedicine:

"The European policy of official multilingualism is unique in the world and actively encourages people to speak and write in their own language (1-3). Nonetheless, new terms and terms of foreign origin are uncritically entering certain languages every day, particularly languages of less populated nations. This happens both in the standard Croatian language and the language of individual professions. Numerous conditions have to be met for a language to achieve internationally recognized status, and one of the fundamental conditions is a systematically established professional terminology for individual professions. An indifferent approach towards establishing Croatian terminology and the uncritical acceptance of loanwords and other word borrowings systematically endangers the survival of the Croatian language and thus its international status.” (Vodanović, Ostroški Anić, 2013, p. 639)

It is important to point out that when speaking about the Croatian language and the need to regulate Croatian professional terminology we are actually speaking about all languages and their professional terminology because everything we said about Croatian also applies to all other languages, particularly those languages that are the official languages of European Union member states. The need to regulate public relations terminology was clearly recognized at the end of the first decade of the $21^{\text {st }}$ century in Slovenia: "Without Slovenian terminology, as has already been noted, Slovenian public relations would simply not exist.” (Kalin Golob, Logar Berginc, 2008). On the website http://www.termis.fdv.uni-lj. si/files/Slovene_Terminologies.pdf the head of a project to compile a text corpus for public relations terminology for the Slovenian language (more on this in item 5 hereof) Nataša Logar replies to the question "What would you say has been the driving force behind this project?" as follows: "In 1998, a leading Slovenian expert on public relations, and a colleague on the project, Dejan Verčič wrote: 'Language is the basic tool of any profession. It is impossible to think without it, or even communicate. Until it is possible to think and communicate about public relations in the Slovenian language, it will be difficult to speak about Slovenian public relations. As long as we do not have our own language to talk about 
a discipline, then in a sense, we still do not have our own discipline.”

Another reason why it is important to regulate professional terminology is the fact that one of the fundamental tasks of every standard language (including Croatian) is to fulfill all the functions a language has in society and that the regulation of professional terminology is an indicator of the regulation of the standard language. The terminology of many older professions has been systematically regulated since the $19^{\text {th }}$ century (Horvat, Hudeček, Mihaljević, 2016). One area in which Croatian terminology has not been systematically regulated and standardized is public relations. ${ }^{4}$

\subsection{Synonymy in Terminology}

With the entry of a new concept in a profession, its name enters professional communication, usually in the language of the country in which the concept and its name emerged; in our time and cultural circle this usually means English terms. Frequently, efforts are made parallel with the entry of a loanword or shortly after the beginning of its use to establish a native term, which often results in the creation of several synonymous native terms due to the uncoordinated activities of different expert groups or experts, and thus synonymous pairs or several different terms emerge. Synonymy is extremely undesirable in terminology as communication among experts must be fully unambiguous. Every mathematician, for example, knows the meaning of the term dužina (line segment) and the meaning of the term duljina (length). Professionally, these terms are precisely defined and cannot be interchanged, although they are synonyms in the general language, where, for example, both dužina kaputa and duljina kaputa can be used (both refer to the length of a coat). Twenty years ago, the terms prijenosno računalo, prijenosnik, laptop and krilovnik were used in Croatian for the same thing, i.e. a laptop. The recommended term in such sequences or pairs is selected through the application of terminological principles as well as collaboration between experts from the relevant profession and linguist terminologists. The role of terminologists is important as the recommended term cannot violate the rules of the Croatian standard

4 On 3 May 2006, the colloquium Communication Science: Scientific Branches and Terminology, which was organized by the Communications Department of the University Department of Croatian Studies, was held, and a collection of papers from the meeting was published in 2007. At this colloquium, numerous communication terminology problems were pointed out, but it has remained the only attempt by communication experts and terminologists to talk about this topic (Hudeček, Mihaljević, 2007). 
language (orthographical, phonological, morphological, syntactical, formative and lexical rules) nor the rules of the scientific functional style of the Croatian standard language (e.g. the status of metaphorical terms in English and Croatian terminology differs - while metaphorization is a regular phenomenon in the former, it is usually avoided in the latter). Sometimes a terminologist will recommend a completely different term if the proposed Croatian term does not comply with the rules of the Croatian standard language or if only the English term is in use and no Croatian equivalents have been established. In the end, however, experts have the final word. In the above case, terminologists deemed the terms prijenosno računalo and prijenosnik to be more acceptable from a linguistic aspect, and out of these two options experts then chose the term prijenosno računalo. Only collaboration between terminologists and experts from the profession in question can lead to the selection of a linguistically correct term that is acceptable to experts.

\subsection{Unofficial and Official Communication: Jargon and Professional Terminology}

Every profession has its own jargon (Halonja, Mihaljević, 2012). It is important to note that the terminology used in jargon does not belong to standard language. It belongs solely to unofficial, informal, casual communication, i.e. it has no place in laws and regulations, textbooks and academic papers or in any form of official communication. Today, the professional jargon of almost any profession frequently contains anglicisms with different degrees of adaptation to the Croatian language. They may be orthographically and phonologically unadapted and pronounced and spelled as in the English language (e.g. pitch, follow-up, case-study, web, $e$-mail) or orthographically and phonologically adapted to the Croatian language (e.g. npr. mejl (< mail), masmedija (< masmedia), menadžer (< manager), imidž (< image)). In both cases they are adapted grammatically to the Croatian language as they possess its morphological characteristics, e.g. case markings (N pitch, G pitcha, D pitchu..., N mejl, G mejla, D mejlu...) and derivatives thereof are formed in accordance with Croatian language rules, e.g. mejlati, trigerirati, PR-ovac, presica. Two-word jargon terms often adhere to the rules of English and not Croatian syntax, even when part of the expression is in Croatian (e.g. follow-up aktivnosti, web-stranice, media lista). Public relations jargon also contains Croatian verbs in conjunction with additions typical for the English language, e.g. komunicirati što used 
as follows: Moramo odlučiti kako ćemo to komunicirati zaposlenicima. (We must decide how to communicate this to employees.) According to the syntax of the Croatian standard language, this verb can only be used in the instrumental case in Croatian: komunicirati s kim (to communicate with somebody), so if used in above sense, a different verb should be used as follows: Moramo odlučiti kako ćemo to prenijeti zaposlenicima / kako ćemo o tome obavijestiti zaposlenike. The terms mejlati, iskomunicirati and presica are used, for example, in the message: Molim te, mejlaj mi upute kako da to iskomuniciram na presici; they belong to jargon terminology and should not be used in official communication, in an administrative and scientific style, nor in most texts written in a journalistic functional style.

Table 1. Professional jargon and professional term
Professional jargon
Professional term
mejlati
poslati (e-)poruku (engl. to mail, to send an e-mail)
iskomunicirati
prenijeti (što) / obavijestiti (o čemu)
(engl. to convey sth./ to inform about sth.)
presica
konferencija za novinare (engl. press conference)

\section{Synonymous Pairs and Sequences in Croatian Public Relations Terminology}

Croatian public relations terminology contains numerous synonymous pairs and sequences, and sometimes three different authors use three different terms in their papers to describe the same concept. Often the same author uses differing terms in the same text part to refer to the same concept. We already pointed out that synonymy is extremely undesirable in terminology. Here are some of the many synonymous sequences and pairs in today's public relations terminology 5 :

- $\mathrm{B} 2 \mathrm{~B}$ - business to business - komunikacija posao - posao, komunikacija među tvrtkama, komunikacija među poslovnim subjektima

- brand - brend - robna marka

- branding - brending - brandiranje - brendiranje

5 The examples in this paper were extracted from the hrWac corpus (http://nlp.ffzg.hr/resources/corpora/hrwac/), Hrvatska jezična riznica (http://riznica.ihjj.hr/index.hr.html) and online literature on public relations. 
- case study - studija slučaja - analiza slučaja

- community management - upravljanje profilom (tvrtke) na društvenim mrežama

- društveno odgovorno poslovanje - društvena odgovornost poduzeća (različito razvezivanje pokrate DOP)

- evaluacija - vrednovanje - vrjednovanje

- event - događaj-događanje

- Facebook profil - Fejsbuk profil - profil na Facebooku

- follow-up aktivnosti - aktivnosti slijeđenja - slijedne aktivnosti - follow-up - folouap - slijeđenje

- interna komunikacija - unutrašnja komunikacija - interno komuniciranje - unutrašnje komuniciranje (u pravilu samo: vanjska komunikacija - vanjsko komuniciranje)

- interno glasilo - unutrašnje glasilo (u pravilu samo: vanjsko glasilo)

- kanal komunikacije - komunikacijski kanal

- klasificirana informacija - povjerljiva informacija

- komunikacijski plan - plan komunikacije

- masovni mediji - mediji masovne komunikacije - mediji masovnog komuniciranja masmediji - masmedija

- media list - media lista - adrema - medijska lista - lista medija - medijski popis - popis medija

- mrežni odnosi s javnošću, internetski odnosi s javnošću, online public relations, online PR, e-PR

- PR, odnosi s javnošću

- PR agencija, piarovska agencija, agencija za odnose s javnošću

- press-konferencija, presica, konferencija za novinare, novinska konferencija, konferencija za medije

- press release - objava za medije - medijska objava

- target - ciljna skupina - ciljana skupina

- trening - radionica - tečaj - edukacija

- web stranica, web-stranica, Internet-stranica, internet-stranica, Internet stranica, Internet stranica, internetska stranica, e-stranica, mrežna stranica ${ }^{6}$.

6 These terms are used as synonyms even though they are not synonyms since mreža (Web) and internet (Internet) do not have the same meaning. 


\section{Terminological Principles and Their Application to Public Relations Terminology}

Terminologists standardize terminology, i.e. they give preference to a certain synonymous pair or sequence over another pair or sequence, in accordance with these fundamental terminological principles ${ }^{7}$ :

1. Native terms take precedence over foreign terms (e.g. robna marka over brand/brend, analiza/studija slučaja over case study).

2. Terms must be adapted to the Croatian standard language, then such terms take precedence over unadapted terms (e.g. regulativna/regulacijska agencija over regulatorna agencija).

3. Terms take precedence over other synonymous terms if they correspond to the concept they were assigned to and reflect their place in the conceptual system (precedence will be given, for example to the term unutrašnja komunikacija over the term interna komunikacija because only the term vanjska komunikacija is used, not eksterna komunikacija).

In addition to these key terminology standardization principles, which will be further discussed hereinafter, the following additional rules, which will only be mentioned here, are also applied in terminology standardization:

4. Latin or Greek terms take precedence over terms from a modern foreign language (e.g. multimediji over multimedija, donator over donor, curriculum vitae over $C V$, licencija over licenca). It is important to note that Croatian terms, if any, take precedence over those borrowed from Latin, so instead of the terms curriculum vitae or licencija it is better to use životopis and ovlasnica.

5. More widely used terms and terms more acceptable to users take precedence over less widely used terms. Based on this rule preference is given, for example, to the term preslika over the term preslik (both words were formed properly: the word preslika from the noun slika, the word preslik from the verb stem slik).

7 The terminological principles and their application are explained and accompanied by examples in Hudeček, Mihaljević, 2012 and in works by these authors on terminologies of many professions (see literature). Terminological standardization in the Struna project is also done according to the rules presented in this rulebook, which was compiled for the purpose of this project. 
6. Shorter terms take precedence over longer ones (e.g. audiomediji over auditivni mediji, infografika over informativna grafika).

7. Terms that can more easily be used as bases for derivatives take precedence over those where derivatives are not possible (primatelj obavijesti over primalac obavijesti, rukovoditelj over rukovodilac; because nouns ending in -telj can be used as a basis for the feminine counterpart such as primateljica obavijesti, rukovoditeljica, which is not possible with nouns ending in -lac).

8. It should be avoided that terms within the same terminology system have several meanings (the abbreviation DOP can stand for both društveno odgovorno poslovanje and društvena odgovornost poduzeća; MSP can stand for both mala i srednja poduzeća and malo i srednje poduzetništvo; although these meanings are close, abbreviations in a given profession should always have the same meaning).

9. Terms should not be modified without a valid reason. This rule applies only to established and properly formed terms of the Croatian language.

It is important to emphasize that not all principles are of equal significance and that rules 1,2 and 3 are superordinated to the others. This means that, in many cases where a shorter English and a longer Croatian term are given, rule 6 cannot be applied. It can only be applied, like the other rules besides the mentioned three, if it does not violate these rules. There are plenty of Croatian terminology dictionaries, but only few of them establish relations between words in a synonymous sequence. This, however, is necessary because the information most often sought by dictionary users is information as to which of the synonymous terms in use are recommended. For this reason, the terminology base Struna has categories clearly indicating which term is recommended (usually appears as a headword) and which terms are in use but not recommended (as non-recommended terms). 


\section{Examples of the Application of Select Terminological Principles to Public Relations Terminology}

\subsection{Rule 1: Native terms take precedence over foreign terms.}

Given the significant representation of anglicisms in Croatian public relations terminology, it is very easy to find examples. A few anglicisms and proposed standard-language substitutions are provided below. ${ }^{8}$

Table 2. Anglicisms in public relations terminology and their Croatian equivalents

\section{Anglicism}

B2B

Brief

briefing/brifing

community relations

Crowdfunding

Event

Feedback

flyer/flajer

impact factor/factor

in-house magazine/newsletter/glasilo

issue management

kick-off sastanak

media list/lista

news/press release

off the record

online public relations, online PR, e-PR

opinion maker

pitch

public relations, PR

target

\section{Croatian term}

komunikacija posao - posao

sažetak

sastanak za novinare

odnosi sa zajednicom

masovno financiranje

događanje

povratna informacija

letak

čimbenik utjecaja

unutrašnje glasilo

upravljanje ključnim temama

uvodni/početni sastanak

popis medija

priopćenje za medije

neslužbeno

mrežni odnosi s javnošću, internetski odnosi s javnošću

oblikovatelj javnoga mišljenja

prodajna/natječajna prezentacija

odnosi s javnošću

cilj, ciljna skupina

8 Substitutes for anglicisms used in Croatian are proposed on the portal Bolje je hrvatski on the website bolje.hr. Some of the suggestions in below table can also be found on this interactive portal. 
When replacing high-frequency anglicisms it is a common concern amongst experts whether message recipients or text readers will understand standard-language terms, as opposed to jargon/English terms, where experts are aware that they might not be the best choice in terms of terminology but they ensure unambiguous communication. It is recommended that in such cases a standard-language term is established and used and should such concerns be given, the English term is stated in brackets when initially using the standard-language term to ensure that the message is fully comprehensible to recipients.

4.1.1. In the above examples, the anglicisms are easily recognized. Anglicisms in the terminology of some professions, however, are not as easily perceived by experts from the profession. This happens very frequently in the following two cases:

1. when false friends are involved and

2. when the terminological rule is violated that, when borrowing is necessary, only the base word is borrowed from the foreign language and its derivatives are formed in accordance with the rules of the language into which the word is being borrowed.

4.1.1.1. The expression "false friends" denotes pairs of words from different languages that sound and/or are spelled alike but have a different meaning (Lewis, 2016). There are many terms in Croatian professional terminology that are false friends of foreign, primarily English terms. Such terms do not belong to professional terminology. False friends are very often the result of the misunderstanding that one loanword corresponds to one Croatian word, e.g. that the only equivalent of the English word training is the word trening in Croatian and that training is always translated as trening, regardless of context. This, however, is not the case. The word training needs to be translated into Croatian as either trening (exclusively in a sports context, including the terms trener, trenerica, trenirati, trenirka) or as radionica, tečaj or izobrazba. The same applies to the following terms: it is incorrect to always translate communication as komunikacija because in English this term also denotes advertising materials or to translate character as karakter, as often the correct translation is znak; classified information should never be translated as klasificirana informacija, only as 
povjerljiva informacija; social network is in principle društvena and not socijalna ${ }^{9}$ mreža; in many contexts, especially in relation to public relations, application and to apply should be translated as prijava or prijaviti se and not as aplikacija or aplicirati. In Croatian, the word aplikacija means 1. primjena, 2. računalni program, 3. nanošenje kakva materijala na drugi, 4. ono što je na što (odjeća, stolnjak itd.) našiveno (Barbarić 2015).

English terms used in public relations must hence be translated depending on the context as one of the two stated Croatian equivalents and not as an equivalent that is pronounced and/or spelled similar to the English term:

training $>1$. trening, 2. radionica/izobrazba (medijski trening $>$ radionica iz odnosa $\mathrm{s}$ medijima, izobrazba za odnose s medijima)

communication > 1. komunikacija, 2. reklamni oglas (stolna komunikacija > stolni reklamni oglas)

character $>1$. znak, 2. karakter (osam karaktera > osam znakova)

social network > 1. socijalna mreža, 2 . društvena mreža (Facebook je socijalna mreža. > Facebook je društvena mreža.)

application > 1. aplikacija, 2. prijava (aplikacija na natječaj > prijava na natječaj)

to applicate $>1$. aplicirati, 2. prijaviti se (aplicirati na natječaj > prijaviti s ena natječaj) classified > 1. klasificiran, 2. povjerljiv (klasificirana informacija > povjerljiva informacija)

scene $>1$. scena, 2. mjesto (scena događanja > mjesto događanja)

4.1.1.2. In public relations terminology the rule that derivatives of loanwords are derived in accordance with the formative rules of the language into which the word is borrowed (language of the recipient) and not borrowed from the language from which the base word was borrowed (language of the donor) is frequently violated (Hudeček, 2016). Thus, in Croatian, for example, the adjective institucijski (institucij + ski) is formed from the loanword

9 In Croatian, the term socijalni is not equivalent to the term društveni. Socijalni refers to "koji se odnosi na zaštitu životnoga standarda (which refers to the protection of a living standard)" (socijalna politika, socijalni rad, socijalni radnik). 
institucija, while the adjective institucionalni is borrowed from English. Such borrowing of derivatives is not supported by the rules of the standard Croatian language and undesirable in either general language or professional terminology. Below are some examples of such borrowing in public relations (Table 3) and examples of the most common collocations with the wrongly established Croatian adjectives (Table 4).

Table 3. Examples of wrongly established Croatian adjectives

\begin{tabular}{|l|l|l|}
$\begin{array}{l}\text { English } \\
\text { adjective }\end{array}$ & $\begin{array}{l}\text { Wrongly established } \\
\text { Croatian adjective }\end{array}$ & $\begin{array}{l}\text { Correctly formed } \\
\text { Croatian adjective }\end{array}$ \\
\hline institutional & institucionalni & institucijski \\
\hline regulatory & regulatorni & regulativni/regulacijski \\
\hline corporate & korporativni & korporacijski \\
\hline promotive & promotivni & promocijski \\
\hline viral & viralni & virusni \\
\hline distributive & distributivni & distribucijski \\
\hline
\end{tabular}

Table 4. Most common collocations with the wrongly established Croatian adjectives

\section{Wrong}

korporativna društvena odgovornost; korporativne komunikacije; korporativni identitet, imidž, lobi, marketing, medij, odnosi s javnošću, PR, pravnik, razvoj, sektor, sustav, vizualni identitet

promotivna akcija, kampanja; promotivni letak, materijal, plakat, prostor, spot, video

institucionalni okvir, razvoj, mehanizmi; međuinstitucionalni program, sporazum, sukob, odnosi, sastanak, dogovor

regulatorna agencija; regulatorni okvir, alati, sustav; regulatorno tijelo

distributivna mreža, distributivni kanal

viralni hit, marketing, sadržaj, video

\section{Correct}

korporacijska društvena odgovornost; korporacijske komunikacije; korporacijski identitet, imidž, lobi, marketing, medij, odnosi s javnošću, PR, pravnik, razvoj, sektor, sustav, vizualni identitet (engl. corporate)

promocijska akcija, kampanja; promocijski letak, materijal, plakat, prostor, spot, video (engl. promotional)

institucijski okvir, razvoj, mehanizmi (engl. institutional); međuinstitucijski program, sporazum, sukob, odnosi, sastanak, dogovor (engl. inter-institutional)

regulativna agencija; regulativni okvir, alati, sustav; regulativno tijelo (engl. regulatory)

distribucijska mreža, distribucijski kanal (engl. distribution)

virusni hit, marketing, sadržaj, video (engl. viral) 


\subsubsection{Abbreviations}

Abbreviations such as PR, OSJ, DOP, B2B and B2C can be frequently found in public relations terminology. Abbreviations taken over from a foreign language, which are usually composed of the beginning letters of several words, can be dealt with in the following three manners:

1. Use the Croatian abbreviation, if given (e.g. $O S J$ instead of $P R, D O P^{10}$ instead of $C S R$ ).

2. If there is no Croatian abbreviation, use the Croatian term (e.g. životopis instead of $C V$, izrezak iz tiska instead of $P C$ (press clip), komunikacija posao - posao instead of B2B).

3. In exceptional cases, a foreign abbreviation is taken over, provided that it is widely used and generally recognized in the profession.

Casually compiled abbreviations such as od.s.jav. have no place in professional terminology or business communication.

\subsection{Rule 2: Terms adapted to standard Croatian take precedence over unadapted terms.}

Given that terminology is an indicator of the stability of a standard language, it must be fully in accordance with its rules on all levels. In the application of this rule, the role of a linguist terminologist ensuring that the recommended term conforms to all rules of the standard language is essential. Below are a few examples of public relations terms violating a standard language rule (orthographical, phonological (Table 5), morphological, formative (Table 6), syntactical or lexical (Table 7)) and the correct term.

10 Explain, also mention MSP. 
Table 5. Public relations terms violating orthographical and/or phonological rules

\begin{tabular}{|c|c|c|c|}
\hline \multicolumn{2}{|c|}{ Orthographical level } & \multicolumn{2}{|c|}{ Phonological level } \\
\hline Wrong & Correct & Wrong & Correct \\
\hline audio-mediji & $\begin{array}{l}\text { audiomediji (engl. audio } \\
\text { media) }\end{array}$ & projekat & projekt (engl. project) \\
\hline $\begin{array}{l}\text { audio-vizualne } \\
\text { komunikacije }\end{array}$ & $\begin{array}{l}\text { audiovizualne komunikacije } \\
\text { (engl. audiovisual } \\
\text { communication) }\end{array}$ & vizualan & vizualan (engl. visual) \\
\hline info-grafika & $\begin{array}{l}\text { infografika (engl. } \\
\text { infographics) }\end{array}$ & $\begin{array}{l}\text { promocijski } \\
\text { matrijal }\end{array}$ & $\begin{array}{l}\text { promocijski material (engl. } \\
\text { promotional material) }\end{array}$ \\
\hline management & $\begin{array}{l}\text { menadžment (engl. } \\
\text { management) }\end{array}$ & menadžment & $\begin{array}{l}\text { menadžment (engl. } \\
\text { management) }\end{array}$ \\
\hline fax & faks (engl. fax) & dizkurs & diskurs (engl. discourse) \\
\hline TV-prijenos & $\begin{array}{l}\text { TV prijenos (engl. TV } \\
\text { broadcast }\end{array}$ & kazeta & kaseta (engl. cassette) \\
\hline Facebookovac & $\begin{array}{l}\text { fejsbukovac (engl. Facebook } \\
\text { user) }\end{array}$ & $\begin{array}{l}\text { e-objava, čitanje: } \\
\text { [i objava] }\end{array}$ & $\begin{array}{l}\text { e-objava, čitanje: } \\
\text { [e objava] (engl. } \\
\text { e-publication) }\end{array}$ \\
\hline
\end{tabular}

Table 6. Public relations terms violating morphological or formative rules

\section{Morphological level}

odnosi s

javnostima

nazivlje OSJ

nazivlje OSJ-a (engl. PR terminology)
Wrong

\section{Formative level}

Wrong Correct

elektronska elektronička komunikacija, komunikacija e-komunikacija

(engl. electronic communication, e-communication)

Iskopirati kopirati (engl. to copy)

iskomunicirati prenijeti (što), obavijestititi (što)

(koga o čemu) (engl. to convey sth., to inform sb. about sth.)

OSJ su OSJ je (engl. PR is)

\begin{tabular}{l|l|l|l} 
videjima & videima (engl. videos) & OSJ su & OSJ je (engl. PR is) \\
$\begin{array}{l}\text { mrežna stranica } \\
\text { tvrtke }\end{array}$ & $\begin{array}{l}\text { mrežne stranice tvrtke (engl. } \\
\text { company website) }\end{array}$ & $\begin{array}{l}\text { komunikacijsko- } \\
\text { kulturni }\end{array}$ & $\begin{array}{l}\text { komunikacijskokulturni } \\
\text { komunikacijska kultura) } \\
\text { (engl. communication } \\
\text { culture) }\end{array}$ \\
\hline sadrže & sadržavaju (engl. contain) & komunikologica & $\begin{array}{l}\text { komunikologinja (engl. } \\
\text { communicologist) }\end{array}$
\end{tabular}


Table 7. Public relations terms violating syntactical or lexical rules

\begin{tabular}{|c|c|c|c|}
\hline \multicolumn{2}{|l|}{ Syntactical level } & \multicolumn{2}{|l|}{ Lexical level } \\
\hline Wrong & Correct & Wrong & Correct \\
\hline $\begin{array}{l}\text { Facebook/ } \\
\text { Fejsbuk profil }\end{array}$ & $\begin{array}{l}\text { profil na Facebooku (engl. } \\
\text { Facebook profile) }\end{array}$ & $\begin{array}{l}\text { cyber- } \\
\text { novinarstvo, } \\
\text { kibernetičko } \\
\text { novinarstvo }\end{array}$ & $\begin{array}{l}\text { kibernovinarstvo (engl. cyber } \\
\text { journalism) }\end{array}$ \\
\hline Google anketa & $\begin{array}{l}\text { anketa na Googleu, } \\
\text { Googleova anketa (engl. } \\
\text { Google survey) }\end{array}$ & Lista & popis (engl. list) \\
\hline komunicirati što & $\begin{array}{l}\text { komunicirati s kim, prenijeti } \\
\text { što (engl. to communicate } \\
\text { with sb., to convey sth.) }\end{array}$ & LCD displej & LCD \\
\hline kontakt-program & $\begin{array}{l}\text { kontaktni program (engl. } \\
\text { contact program) }\end{array}$ & $\begin{array}{l}\text { prime time } \\
\text { termin }\end{array}$ & $\begin{array}{l}\text { udarni termin (engl. prime } \\
\text { time) }\end{array}$ \\
\hline $\begin{array}{l}\text { korporacijski } \\
\text { predsjednik }\end{array}$ & $\begin{array}{l}\text { predsjednik korporacije } \\
\text { (engl. president of } \\
\text { corporation) }\end{array}$ & SMS poruka & SMS \\
\hline $\begin{array}{l}\text { Sistem } \\
\text { administrator }\end{array}$ & $\begin{array}{l}\text { administrator sustava (engl. } \\
\text { system administrator) }\end{array}$ & web-stranica & $\begin{array}{l}\text { mrežna stranica (engl. } \\
\text { website) }\end{array}$ \\
\hline OSJ su & OSJ je (engl. PR is) & print mediji & $\begin{array}{l}\text { tiskani mediji (engl. print } \\
\text { media) }\end{array}$ \\
\hline
\end{tabular}

\subsection{Rule 3: Terms take precedence over other synonymous terms if they correspond to the concept they were assigned to and reflect their place in the conceptual system.}

According to this rule, all terms should be standardized by taking into account the terms associated with it in a cohyponymous relationship, i.e. terms which are on the same hierarchical level and which have the same hypernym, and its antonyms. An example of this is odnosi s javnošću - odnosi s medijima - odnosi sa zajednicom. In public relations, the synonymous expressions unutrašnja komunikacija and interna komunikacija are used, but usually only the expression vanjska komunikacija is used, not eksterna komunikacija. According to rule 1 of terminological standardization, preference should be given to terms containing the native words unutrašnji and vanjski, which is additionally reinforced by the 
fact that the expression eksterna komunikacija, which would be the appropriate antonym to the expression interna komunikacija, is not used. Precedence would also be given to the adjective unutrašnji in other expressions in which equivalent terms are used containing the adjectives interni/unutrašnji, e.g. unutrašnji stručnjaci za odnose s javnošću (i vanjski stručnjaci za odnose s javnošću), unutrašnja javnost (i vanjska javnost), etc.

\section{Guidelines for Regulating Public Relations Terminology}

We already mentioned that there are many terminological dictionaries providing synonymous terms while failing to answer frequent inquiries by experts, translators and proofreaders as to which of the synonymous terms stated in the dictionary are best used, although this is the most frequently posed terminology-related question. For this reason, every profession, including public relations, must develop during the systematization of its terminology a normative terminological dictionary for the profession in question. The development of such a dictionary requires the collaboration of experts and terminologists, including a computer expert as lexicography nowadays practically equates to e-lexicography, and every relevant dictionary must be corpus-based and compiled in line with topical e-lexicography/eterminography knowledge that includes the use of advanced corpus search tools such as SketchEngine and dictionary-making programs facilitating its maintenance and upgrading as well as easy migration to websites. Therefore, the aim of all efforts to regulate public relations terminology should be to develop a terminological dictionary for the profession in question through the following stages:

- Gathering of a team that will necessarily include a public relations expert and terminologist as well as a computer expert and establishment of material prerequisites for the making of a dictionary

- Compilation of an easy-to-search (thematized) corpus of texts dealing with public relations (textbooks, academic papers, legal texts, rulebooks, etc.)

- Selection of a corpus search tool, a dictionary-making program, drawing up precise instructions for lexicographic terminology processing 
- Creation of a corpus-based normative e-dictionary that can be continually updated and expanded.

In Slovenia, the TERMIS project, within the framework of which the KoRP corpus of public relations texts was compiled, was concluded in 2007 and the Termania ${ }^{11}$ database available at http://www.termania.net $/{ }^{12}$ was established between 2011 and 2013. In the conclusion of the paper Terminologija odnosa s javnošću u slovenskome jeziku (Public Relations Terminology in the Slovenian Language) those who participated in the project, which was led by Nataša Logar, $\mathrm{PhD}$, state as follows: "On the example of the TERMIS project, within the framework of which a dictionary for Slovenian public relations terminology was created, we tried to show how it is possible to respond to two challenges the Slovenian (and Croatian) language is facing: at a time when it is necessary to internationalize professions and when their responsible holders must open up internationally for the full functionality of the national language, it should be fully supported digitally using the tools provided by digitalization. (...) Current and future professional linguistic sources will only reach the middle-aged, younger and young generations if they are available online free of charge, if they are modern and regularly updated and if they provide quick answers to current terminological concerns...”

\section{Small Public Relations Dictionary}

In this small dictionary, which serves as an example of how to regulate normative relations amongst synonymous pairs, the > symbol is used to indicate terms used in professional jargon (often an English word or expression) and the relevant term in standard Croatian. Apart from the standard-language terms (those behind the > symbol), English terms are provided as well to ensure their uniformity and facilitate translation from Croatian into English and vice versa, synonymous terms that are part of professional jargon (marked with žarg.) and the definition of meaning. This small dictionary does not contain examples of use or descriptions of the semantic relations between the terms, which would be useful in a bigger dictionary.

\footnotetext{
11 More than 50 public relations experts and the Public Relations Society of Slovenia participated in the making of this database, while the Public Agency of the Republic of Slovenia for Research Activity recognized the value of this project and supported it financially. 12 More information on the TERMIS project is available on the portal http://www.termis.fdv.uni-li.si/.
} 
B2B (eng. business to business) > komunikacija posao - posao

B2C (eng. business to customer) > komunikacija posao - potrošač

briefing (za novinare) > sastanak za novinare

brief > sažetak

copywriting > oglašivačko pisanje

događanje (eng. event) događaj kojemu je cilj promocija ili predstavljanje određene teme, organiziran kao svečanost, natjecanje, konferencija, festival, politički, zabavni ili sportski događaj

donacija (eng. donation) dar u obliku novca, usluga, predmeta, humanitarne ili medicinske pomoći koji daju fizičke ili pravne osobe za određenu, uglavnom dobrotvornu, svrhu

društveno odgovorno poslovanje (DOP) (eng. corporate social responsibility, CSR) poslovanje koje uključuje društvene obveze tvrtke i njezinu odgovornost prema okolišu i zajednici u kojoj posluje, a zadatak je odnosa s javnošću učinkovita komunikacija koja izgrađuje korporacijsku odgovornost i pridonosi jasnomu poslovanju

evaluacija > vrednovanje

event $>$ događanje

interne komunikacije > unutrašnje komunikacije

interno glasilo > unutrašnje glasilo

issue management > upravljanje ključnim temama

izobrazba za odnose s medijima (žarg. medijski trening) (eng. media training) obuka za odnose s različitim vrstama medija i novinarima te držanje prezentacija budućim klijentima

javni poslovi, lobiranje (eng. public affairs, lobbying) aspekt odnosa s javnošću koji uključuju odnose s vladinim ili nadležnim ustanovama ili njihovim poluslužbenim organizacijama u svrhu postizanja cilja putem sofisticiranoga korištenja političke inteligencije i pritiska 
komunikacija posao - posao (komunikacija među tvrtkama, komunikacija među poslovnim subjektima) (eng. B2B, business to business) komunikacija usmjerena razmjeni informacija (o uslugama, obuci, ljudskim potencijalima, uredskim potrepštinama) među poslovnim subjektima

komunikacija posao - potrošač (komunikacija između tvrtke i potrošača) (eng. B2C, business to customer) komunikacija usmjerena razmjeni informacija između tvrtke i potrošača

konferencija za novinare (eng. press conference) događaj organiziran kako bi se medijima predstavila neka vijest te kako bi se predstavnicima medija osiguralo mjesto i vrijeme da o predstavljenoj temi postave pitanja, snime fotografije, videoprilog ili audioprilog

korporacijske komunikacije (eng. corporate communications) korporacijski odnosi s javnošću koji su uključeni u strateške ciljeve tvrtke

krizno komuniciranje (eng. crisis management) jedna od najsloženijih tehnika odnosa s javnošću koja uključuje čitav niz aktivnosti prije, tijekom i nakon krizne situacije; zahtijeva model komunikacije (javni nastupi, izjave i objave za medije, konferencije za novinare...) te vremenski plan, a podrazumijeva i predviđanje mogućih problema i planiranje u slučajevima buduće krize

medijski trening > izobrazba za odnose s medijima

mrežni odnosi s javnošću; internetski odnosi s javnošću (eng. online public relations, online PR, e-PR) mrežna komunikacija te primjena novih tehnologija (društvenih mreža) radi učinkovitijega komuniciranja s javnošću

odnosi s javnošću (eng. public relations, PR) svjesno, planirano i trajno nastojanje da se $u$ javnosti razumije uloga neke organizacije, izgradi i njeguje njezin ugled i povjerenje u nju; upravljanje ugledom

odnosi s javnošću u financijskome sektoru (eng. financial public relations, financial PR) odnosi s javnošću usmjereni razumijevanju potrošača, njihovih navika i načina kako na njih utjecati, tržišnoga položaja tvrtki i korporacijskih procesa kao što su inicijalna javna ponuda, spajanje i akvizicija, privatizacija i neprijateljsko preuzimanje 
odnosi s medijima (eng. media relations) uspostavljanje i održavanje dobrih radnih odnosa s novinarima tiskanih i elektroničkih medija

odnosi sa zajednicom (eng. community relations) korporacijski društveni programi osmišljeni kako bi gradili odnose sa susjedima u lokalnoj zajednici i razvijali njihovo razumijevanje uloge tvrtke

oglašivačko pisanje (eng. copywriting) pisanje tekstova (izravnim i jezgrovitim stilom) za oglašavanje, marketing ili mrežne stranice

online PR > mrežni odnosi s javnošću, internetski odnosi s javnošću

pitch > prezentacija

pokroviteljstvo (eng. sponsorship) financijska ili druga podrška koju tvrtka daje pravnoj ili fizičkoj osobi ili zajednici, pri čemu obje strane ostvaruju korist, primjerice, tvrtka pokrovitelj može povećati svoju prepoznatljivost ili prepoznatljivost svojih proizvoda kod ciljnih javnosti ili stvoriti/poboljšati imidž

prezentacija (eng. pitch) predstavljanje temeljito pripremljenoga, preporučenoga programa i idejnoga rješenja odnosa $s$ javnošću s uključenim troškovnikom. priopćenje za medije (eng. news/press release) izjava koja opisuje događaj ili proizvod za koji se smatra da je zanimljiv općoj javnosti te zaslužuje mjesto u medijima sastanak za novinare (eng. briefing) događaj organiziran za pomno odabrane novinare kako bi im se o čemu dale iscrpnije informacije

sažetak (eng. brief) kratak dokument u kojemu su navedeni zahtjevi i ciljevi klijenta koji se odnose na određeni projekt; definira očekivanja klijenta i agencije te je sastavni dio konačnih ugovornih obveza i referentni dokument prema kojemu se može objektivno mjeriti rad i učinak agencije

sponzorstvo > pokroviteljstvo

unutrašnje glasilo (eng. in-house magazine/newsletter) glasilo kojim se komunicira sa zaposlenicima, u pravilu uključuje vijesti, važna pitanja te zbivanja povezana s tvrtkom $\mathrm{u}$ kojoj rade 
unutrašnje komunikacije (eng. internal communications) komunikacije koja pomažu pri ostvarenju korporacijskih ciljeva, a uključuju različite komunikacijske procese te komunikaciju sa zaposlenicima i dioničarima.

upravljanje ključnim temama (eng. issue management) upravljanje temama ključnim za poslovanje, kojemu je svrha mu je osigurati da svi problemi tijekom provedbe kakva projekta budu prepoznati navrijeme

vrednovanje (eng. evaluation) mjerenje utjecaja kampanje odnosa s javnošću, izravno je povezano s planiranjem i istraživanjem

\section{Conclusion}

For the development of a profession it is extremely important to have a consistently regulated terminology that facilitates unambiguous communication among experts and which follows all of the rules of the standard language it belongs to. Because "consistent, regulated and accessible terminology is an extremely important basis to guarantee true multilingualism in the European Union" (Hudeček, Mihaljević, 2012, p. 9) and since this is recognized today by experts from many professions as well as Croatian laws and regulations in relation to scientific work and the acquisition of academic titles, it is necessary to start regulating public relations terminology as soon as possible by developing a reliable normative dictionary clearly stating recommended terms (which are defined in line with all terminology standardization principles stated herein), the register of equivalent terms not recommended (e.g. jargon, archaic), definitions of meanings established by experts and edited by terminographers/terminologists, examples of meanings, superordinated, subordinated and hierarchically equivalent terms (hypernyms, hyponyms and cohyponyms) as well as equivalents in several world languages. 


\section{Reference List}

- Barbarić, V.-T. (2015). Kad engleski nije komad torte. Hrvatski jezik, 2/4, 30-32.

- Halonja, A., Mihaljević, M. (2012). Od računalnoga žargona do računalnoga nazivlja. Zagreb: Hrvatska sveučilišna naklada.

- Horvat, M., Hudeček, L., Mihaljević, M. (2015). Jezik hrvatskih znanstvenih tekstova u 19. stoljeću. In: Povijest hrvatskoga jezika. 4. knjiga: 19. stoljeće (pp. 301-357). Zagreb: Croatica.

- Hudeček L., Matković, M., Ćutuk, I. $\left(2011,{ }^{1} 2012^{2}\right)$. Jezični priručnik Coca-Cole HBC Hrvatska. Zagreb: Coca-Cola HBC Hrvatska. Retrieved from: www.priručnik.hr. 1 December 2017.

- Hudeček, L. (2011). Zašto su respektivno, instantno i mandatorno lažni prijatelji?. Jezik: časopis za kulturu hrvatskoga književnog jezika, 58 (5), 191-193.

- Hudeček, L., Ćutuk, I. (2012). Normiranje naziva u poslovnome jeziku. Liburna - Međunarodni znanstveni časopis za kulturu, turizam i komuniciranje, 1 (1), 60-73.

- Hudeček, L., Mihaljević, M., Pupovac, V. (2009). Pojmovnik. In: Kern, J., Petrovečki, M. (Eds.), Medicinska informatika (pp. 373-377). Zagreb: Medicinska naklada.

- Hudeček, L., Mihaljević, M. (2007). Primjena terminoloških načela na komunikološko nazivlje. In: Mataušić, J. M. (Ed). Komunikacijske znanosti: znanstvene grane i nazivlje (pp. 120-136). Zagreb: Hrvatski studiji Sveučilišta u Zagrebu.

- Hudeček, L., Mihaljević, M. (2009). Načela normiranja hrvatskih naziva s primjerima iz medicinskog nazivlja. In: Ledinek, N., Žagar Karer, M., Humar, M. (Eds.), Terminologija in sodobna terminografija (pp. 97-110). Ljubljana: Institut za slovenski jezik Frana Ramovša ZRC SAZU.

- Hudeček, L., Mihaljević, M. $\left(2009^{1}, 2011^{2}, 2012^{3}\right)$. Hrvatski terminološki priručnik. Zagreb: Institut za hrvatski jezik i jezikoslovlje.

- Hudeček, L., Mihaljević, M. (2011). Jezična i terminološka analiza nekih naziva iz Euroterma. In: Bratanić, M. (Ed.), Hrvatski jezik na putu u EU (pp. 223-240). Zagreb: Institut za hrvatski jezik i jezikoslovlje, Hrvatska sveučilišna naklada.

- Hudeček, L., Mihaljević, M., Vidović, D. (2006). Sinonimni parovi i nizovi u temeljnome jezikoslovnom nazivlju. Filologija, 46-47, 101-122

- Hudeček, L., Sajter, D. (2009). Temeljni pojmovi i nazivi stečajnoga prava. Rasprave Instituta za hrvatski jezik i jezikoslovlje, 35 (1), 309-331.

- Hudeček, L. (2012). Terminološka načela u Coca-Colinu priručniku. Jezik: časopis za kulturu hrvatskoga književnog jezika, 59 (3), 106-108.

- Hudeček, L. (2016). Je li agencija regulatorna ili regulativna. Hrvatski jezik, 3 (2), 26-27.

- Hudeček, L., Mihaljević, M. (2015). Relations between Description and Prescription in Croatian Language Manuals. In: Smolej, M. (Ed.), Slovnica in slovar - aktualni jezikovni opis (pp. 299-309). Ljubljana: Znanstvena založba Filozofske fakultete.

- Kalin Golob, M., Logar Berginc, N. (2008). Globalisation and the formulation of technical terms: is there still a need for terminology in national languages?. Strani jezici, 4, 435-540.

- Lewis, K. (2016). Četiri riječi, novi mačci u vreći: aplikacija, autoritet, divizija i rezolucija. Hrvatski jezik, 3 (3), $31-34$.

- Lewis, K. (2016). Lažni prijatelji. Zagreb: Institut za hrvatski jezik i jezikoslovlje.

- Logar Berginc, N., Verčič, D., Kalin Golob, M. (2013). Terminologija odnosa s javnošću u slovenskome jeziku. Medijske studije, 4 (7), 94-109.

- Vodanović, M., Ostroški Anić, A. (2013). Hrvatsko biomedicinsko nazivlje - izazov za jezikoslovce. JAHR - European Journal of Bioethics, 4 (7), 639-644.

\section{Internet Sources}

- Hrvatska jezična riznica (Craoatian language repository). Retrieved from: http://riznica.ihjj.hr/index.hr.html. 29 November 2017.

- Interwiev with head of the TERMIS project - Nataša Loga. Retrieved from: http://www.termis.fdv.uni-lj.si/files/Slovene_ Terminologies.pdf. 29 November 2017.

- Korpus hrWac (hrWac corpus). Retrieved from: http://nlp.ffzg.hr/resources/corpora/hrwac/. 29 November 2017.

- Portal Bolje je hrvatski (Portal It’s better in Croatian). Retrieved from: www.bolje.hr. 29 November 2017.

- Pravilnik o izboru u znanstvena zvanja (Rulebook on Awarding of Academic Titles). Retrieved from: http://narodnenovine. nn.hr/clanci/sluzbeni/2017_03_28_652.html. 29 November 2017.

- Termania database. Retrieved from: http://www.termania.net/. 29 November 2017.

- TERMIS project. Retrieved from: http://www.termis.fdv.uni-lj.si/. 29 November 2017. 


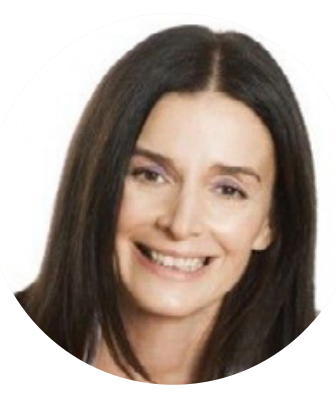

\section{Lana Hudeček}

Lana Hudeček is a tenured scientific advisor at the Institute of Croatian Language and Linguistics. In her scientific work she primarily deals with contemporary linguistic norms, terminology, lexicology and lexicography, language in business communication, language in the media and the history of language. She is the author of several books (including basic normative manuals) and many papers in this area. She is the editor of the linguistic advice portals jezični-savjetnik. $h r$ and Bolje je hrvatski (bolje.hr) as well as the scientific and popular magazine Hrvatski jezik. She is also a member of the editorial board of the magazine of the Institute of Croatian Language and Linguistics Rasprave: Časopis Instituta za hrvatski jezik i jezikoslovlje. She is the head of the research project Hrvatski mrežni rječnik - MREŽNIK of the Croatian Science Foundation and an institute project on religious orthography (Religijski pravopis). She is a member of the International Committee of Slavonic Scholars, Terminology Commission, the organizational committee of the conference Croatian Syntactic Days (Hrvatski sintaktički dani) and the Language and Speech Council (Savjet za jezik i govor) of Croatian Radiotelevision. She teaches at the University of Applied Sciences Vern', has participated in lectures at many Croatian universities and held guest lectures and workshops in Croatia and abroad.

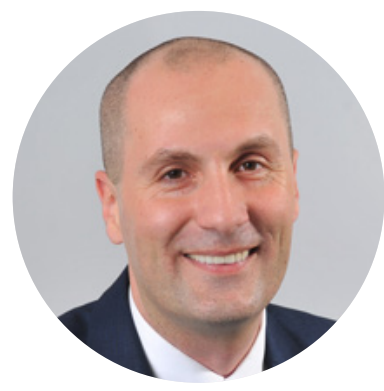

Igor Ćutuk

Igor Ćutuk holds a master's degree in journalism and public relations. In addition to a successful career as a radio journalist and foreign correspondent, his activities as well as his scientific and professional work are aimed at raising the level of business communication. Over the years, he has gained extensive experience in communications and public relations, mainly at CocaCola HBC Croatia, where he worked from 2008 to 2015. During this time he realized several internationally acknowledged and awarded projects such as Our Beautiful Sava, Bike to Work, The Language Manual of Coca-Cola HBC Croatia and many others. Since July 2015 he has been Head of Corporate Communications and the spokesperson of Croatian Radiotelevision. He is a member of the Management Board of the Croatian Public Relations Association (CPRA) and a lecturer at the University Department of Croatian Studies, University of Zagreb. He is currently enrolled in a $\mathrm{PhD}$ programme in information and communication sciences at the Faculty of Humanities and Social Sciences, University of Zagreb. 